УДК 342.925(477)

\author{
А. Осадчий, \\ кандидат юридичних наук, доцент, \\ доцент кафедри адміністративного і фінансового права \\ Національного університету «Одеська юридична академія»
}

\title{
СУЧАСНИЙ КОНЦЕПТ УКРАЇНСЬКОЇ АДМІНІСТРАТИВНОЇ ЮСТИЦІї
}

Формування ефективного механізму захисту прав у правовій державі передбачає функціонування дієвого судового порядку захисту прав у публічно-правових відносинах. Сьогодні такій порядок пов'язаний в Україні з функціонуванням адміністративної юстиції. При цьому ефективне функціонування цього відносно нового різновиду правосуддя потребує розв'язання насамперед низки науково-теоретичних проблем, що $€$ умовою подальшого належного правового регулювання адміністративної юстиції, а отже, і підвищення рівня захисту прав фізичних і юридичних осіб у публічно-правових відносинах, насамперед у сфері публічного адміністрування.

Проблематиці дослідженні теоретичних засад адміністративної юстиції в сучасній адміністративно-правовій науці присвячені численні праці таких вітчизняних учених, як В.Б. Авер'янов, І.О. Картузова, С.В. Ківалов, І.Б. Коліушко, Р.О. Куйбіда, Ю.С. Педько, Н.Б. Писаренко, В.П. Тимощук та ін. Проте в доктрині адміністративного права нині відсутні сталі підходи до розуміння сутності адміністративної юстиції, її співвідношення з адміністративним судочинством.

Метою статті є дослідження змісту інституту української адміністративної юстиції як різновиду правосуддя, що відправляється у формі адміністративного судочинства (адміністративного процесу).

У сучасній правовій державі правозахисна функція судової влади поширюється не тільки на випадки, коли правовий порядок порушують фізичні та юридичні особи, а й на випадки, коли його порушують органи публічної влади, їхні посадові чи службові особи [1, с. 7]. Основним різновидом діяльності, через який реалізується судова влада, є правосуддя. Під правосуддям розуміється діяльність, що здійснюється виключно судами (ч. 1 ст. 124 Конституції Україн) в особливій процесуальній формі (судочинство) шляхом розгляду й вирішення юридичних (правових) спорів i в передбачених законом випадках також інших справ (ч. 3 ст. $124 \mathrm{Koн-}$ ституції України). Оскільки публічне адміністрування $є$ діяльністю, під час якої забезпечується практична реалізація більшості з наданих особі Конституцією та законами України прав, виконання покладених на неї обов'язків, цілком природно, що найбільша кількість правових спорів щодо реалізації фізичними та юридичними особами іхніх прав, інтересів, виконання обов'язків у сфері публічно-правових відносин виникає саме в цій сфері.

Для судового вирішення таких спорів (які позначаються як публічно-правові спори) в Україні, так само як і в багатьох провідних демократичних країнах, функціонує інститут адміністративної юстиції. Адміністративна юстиція - це різновид правосуддя, предметом якого здебільшого є публічно-правові спори, що реалізується у формі адміністративного судочинства на основі судової спеціалізації. Виходячи $з$ наведеної дефініції, можна визначити характерні риси адміністративної юстиції, які в сукупності дають 


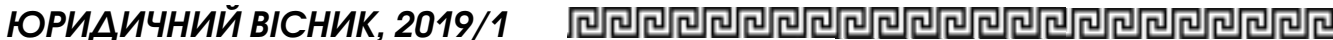

змогу правильно розуміти ї сутність, відмежовувати адміністративну юстицію від діяльності з вирішення публічно-правових спорів, що здійснюється в позасудовому порядку або в порядку цивільного судочинства тощо, що іноді ототожнюються 3 адміністративною юстицією [2, с. $19 ; 3$, с. 78 ; 4, с. 13-21; 5, с. 57-65]. Отже, можна визначити такі характерні риси цього різновиду правосуддя:

1) адміністративна юстиція спрямована на розгляд і вирішення здебільшого публічно-правових спорів у зв'язку з порушенням прав, свобод, інтересів фізичних і юридичних осіб у сфері публічного адміністрування (у Кодексі адміністративного судочинства (далі - КАС) України функції публічного адміністрування позначаються як публічно-владні управлінські функціiі) - матеріальний аспект;

2) адміністративна юстиція здійснюється в особливому законодавчо встановленому порядку (процесуальній формі) - у формі адміністративного судочинства (адміністративний процес), що пристосовано саме для найбільш ефективного розгляду публічно-правових спорів та інших справ у публічно-правовій сфері, - процесуальний аспект;

3) адміністративна юстиція реалізується на основі судової спеціалізації спеціалізованими судами (адміністративні суди) - організаційний аспект.

Як бачимо, адміністративне судочинство виступає як процесуальний складник адміністративної юстиції - форма реалізації цього різновиду правосуддя. Наведений погляд на співвідношення судочинства (процесу) та правосуддя підтримується як вченими-адміністративістами, так і правниками, які займаються проблематикою інших процесуальних галузей права [6, с. 47; 7, с. 32]. Отже, під адміністративним судочинством (адміністративним процесом) розуміється встановлений законом порядок діяльності адміністративних судів з розгляду та вирішення публічно-правових спорів і деяких інших справ у випадках, передбачених законом. Адміністративне судочинство як порядок відправлення правосуддя адміністративним судами визначено спеціалізованим законодавчим актом -KAC України.

3 вищенаведеними рисами адміністративної юстиції тісно переплетено завдання адміністративного судочинства, що визначено ч. 1 ст. 2 KAC України й водночас $є$ й завданням адміністративної юстиції, оскільки співвідношення цього різновиду правосуддя та адміністративного судочинства $€$ співвідношенням змісту й форми. Завданням адміністративного судочинства $€$ справедливе, неупереджене i своєчасне вирішення судом спорів у сфері публічно-правових відносин 3 метою ефективного захисту прав, свобод та інтересів фізичних осіб, прав та інтересів юридичних осіб від порушень з боку суб'єктів владних повноважень.

3 аналізу завдання адміністративного судочинства стає зрозумілим значення цього інституту для розвитку демократичної, правової держави загалом. Стаття 3 Конституції України встановлює, що «людина, іï життя і здоров'я, честь і гідність, недоторканність і безпека визнаються в Україні найвищою соціальною цінністю. Права і свободи людини та їх гарантії визначають зміст і спрямованість діяльності держави. Держава відповідає перед людиною за свою діяльність. Утвердження i забезпечення прав і свобод людини є головним обов'язком держави». Як зазначає I.O. Картузова, встановлення в Основному Законі країни такого положення $€$, безумовно, великим досягненням демократії, але без існування механізму, точніше, багатьох механізмів реалізації захисту прав, свобод та інтересів фізичних і юридичних осіб від свавілля владних суб'єктів воно може залишитися лише теорією. Саме адміністративне судочинство в Україні покликане виконувати роль одного з таких важливих механізмів гарантів прав громадян [1, с. 17]. 
Задля реалізації завдання адміністративного судочинства адміністративні суди, вирішуючи питання щодо захисту прав, свобод та інтересів фізичних і юридичних осіб від порушень з боку суб'єктів владних повноважень під час прийняття ним рішень, учинення дій чи бездіяльності, перевіряють, чи прийняті (вчинені) вони (ч. 2 ст. 2 КАС України): 1) на підставі, у межах повноважень і в спосіб, що визначені Конституцією та законами України; 2) з використанням повноваження з метою, з якою це повноваження надано; 3) обгрунтовано, тобто з урахуванням усіх обставин, що мають значення для прийняття рішення (вчинення діï); 4) безсторонньо (неупереджено); 5) добросовісно, тобто з щирим наміром щодо реалізаціï владних повноважень і досягнення поставлених цілей і справедливих результатів [8, с. 42]; 6) розсудливо, тобто відповідно до здорового глузду та загальноприйнятих моральних стандартів [8, с. 42]; 7) з дотриманням принципу рівності перед законом, запобігаючи всім формам дискримінації 8) пропорційно, зокрема 3 дотриманням необхідного балансу між будь-якими несприятливими наслідками для прав, свобод та інтересів особи й цілями, на досягнення яких спрямоване це рішення (дія); 9) з урахуванням права особи на участь у процесі прийняття рішення; 10) своєчасно, тобто протягом розумного строку.

Зважаючи на гарантоване ч. 2 ст. 55 Конституції України кожному право на оскарження в суді рішень, дій чи бездіяльності органів державної влади, органів місцевого самоврядування, посадових і службових осіб, кожна фізична чи юридична особа має право звернутися до адміністративного суду, якщо вважає, що рішенням, дією чи бездіяльністю суб'єкта владних повноважень порушені іï права, свободи або законні інтереси (за умови дотримання досудового порядку врегулювання спору, якщо обов'язковість досудового урегулювання прямо встановлена законом). Проте у випадках, передбачених законом, до адміністративного суду можуть звертатися не тільки фізичні та юридичні особи, а й суб'єкти владних повноважень. Такі випадки здебільшого пов'язані із судовим санкціонуванням прийняття певних рішень і вчинення певних дій, які пов’язані з реалізацією суб'єктами владних повноважень тих т. зв. «втручальних повноважень», що тягнуть суттєве обмеження прав і законних інтересів фізичних чи юридичних осіб у тому числі через покладення на них обтяжливих обов'язків (установлення обмеження щодо реалізації права на мирні зібрання, примусовий розпуск об'єднань громадян, примусове видворення іноземців та осіб без громадянства за межі України тощо) [1, с. 310]. У цьому разі суд, зважаючи на завдання адміністративного судочинства, здійснює попередній контроль за діями, якими суттєво зачіпаються права особи, і тим самим здійснює й запобіжний захист прав, свобод та інтересів особи, яка $€$ відповідачем за адміністративним позовом суб'єкта владних повноважень [8, с. 138].

Отже, адміністративний суд здійснює захист прав, свобод, інтересів фізичних і юридичних осіб:

1) у разі звернення їх до суду з позовом до суб'єкта владних повноважень - шляхом перевірки правомірності рішень, дій чи бездіяльності останнього;

2) у разі звернення до суду суб'єктів владних повноважень - шляхом санкціонування в установлених законом випадках (через перевірку наявності підстав для реалізаціі відповідних повноважень) прийняття ними певних рішень і вчинення певних дій стосовно фізичної чи юридичної особи.

У разі звернення до адміністративного суду фізичної чи юридичної особи захист ї прав, свобод та інтересів здійснюється певними способами судового захисту. Під способами судового захисту розуміються матеріально-правові заходи примусового характеру, що вживаються судом і за допомогою яких проводиться ефективне понов- 


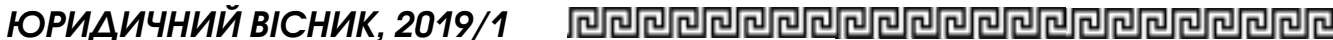

лення порушених прав, свобод, інтересів особи. Визначенню способів судового захисту, які можуть застосовуватися адміністративними судами, присвячено ст. ст. 5 і 245 КАС України. Способи судового захисту поділяються на встановлені законом і визначені судом (такі, що не суперечать закону й забезпечують ефективний захист прав, свобод, інтересів). За загальним правилом, суд здійснює захист порушених прав, свобод, інтересів одним із передбачених законом способів. Відповідно до ч. 1 ст. 5 КАС України, встановлено такі способи судового захисту: 1) визнання протиправним і нечинним нормативно-правового акта чи окремих його положень; 2) визнання протиправним і скасування індивідуального акта чи окремих його положень; 3) визнання дій суб’єкта владних повноважень протиправними та зобов'язання утриматися від учинення певних дій; 4) визнання бездіяльності суб’єкта владних повноважень протиправною та зобов'язання вчинити певні дії; 5) установлення наявності чи відсутності компетенції (повноважень) суб'єкта владних повноважень. Водночас із ужиттям зазначених вище способів судового захисту адміністративний суд може також вирішити питання про відшкодування шкоди, заподіяної протиправними рішеннями, діями чи бездіяльністю суб'єкта владних повноважень або іншим порушенням прав, свобод та інтересів суб'єктів публічно-правових відносин, або вимоги про витребування майна, вилученого на підставі рішення суб’єкта владних повноважень. Інакше такі вимоги вирішуються судами в порядку цивільного або господарського судочинства.

Натомість, коли застосування передбачених законом способів судового захисту не здатне забезпечити ефективний захист, задля реалізації завдання адміністративного судочинства адміністративний суд здійснює судовий захист також у спосіб, який прямо законом не передбачений, проте не суперечить йому і здатен забезпечити ефективний захист прав, свобод, інтере- сів особи від порушень з боку суб'єкта владних повноважень (ч. 2 ст. 5, п. 11 ч. 2 ст. 245 КАС України).

Способи захисту, які необхідно вжити суду, визначає сама особа в позовній заяві. У тому числі в позовній заяві можуть бути зазначені й не передбачені законом способи судового захисту, які забезпечують ефективний захист прав, свобод, інтересів від порушень з боку суб'єктів владних повноважень. Крім того, суд може вийти за межі позовних вимог, якщо це необхідно для ефективного захисту прав, свобод, інтересів людини та громадянина, інших суб'єктів у сфері публічно-правових відносин від порушень з боку суб'єктів владних повноважень (ч. 2 ст. 9 КАС України), тобто суд може вжити способи судового захисту, які не зазначені в позовній заяві, якщо способи судового заходу, про застосування яких просить особа, не забезпечують ефективного захисту прав, свобод, інтересів. У кінцевому підсумку вибір відповідного способу судового захисту залежить від змісту конкретного права, свободи, інтересу й характеру його порушення.

Під час звернення до адміністративного суду суб'єктів владних повноважень з позовом до фізичної чи юридичної особи суд, як уже зазначалося, здійснює попередній контроль за правомірністю рішення чи дії суб'єкта владних повноважень - вимоги суб'єкта владних повноважень задовольняються судом за умови, якщо ними не порушуються права, свободи, інтереси особи. Відповідно, у рішенні адміністративного суду зазначаються не способи судового захисту прав, свобод, інтересів особи, а санкціонується прийняття певних рішень чи вчинення певних дій суб'єктом владних повноважень.

Підсумовуючи все вищенаведене, варто констатувати, що адміністративна юстиція за своїм змістом є проявом такого різновиду публічно владної діяльності, як правосуддя. Формою реалізації цього різновиду діяльності, що відбиває іï сутнісні характеристики, $€$ адміністративне судочинство (адміні- 
стративний процес). Завдання адміністративної юстиції та адміністративного судочинства щодо ефективного захисту прав, свобод та інтересів у сфері публічно-правових відносин, пов'язаних насамперед із публічним адмініструванням, реалізуються як у разі звернення до адміністративного суду фізичної чи юридичної особи, так і в разі звернення до адміністративного суду суб'єкта владних повноважень з позовом до фізичної чи юридичної особи.

Ключові слова: правосуддя, адміністративна юстиція, адміністративне судочинство, адміністративний процес, завдання адміністративного судочинства, способи судового захисту.

Стаття присвячена дослідженню змісту інституту української адміністративної юстиції як різновиду правосуддя, предметом якого здебільшого є публічно-правові спори, що реалізується у формі адміністративного судочинства (адміністративного процесу) на основі судової спеціалізаціі. Розкрито характерні риси адміністративної юстиції, завдання адміністративного судочинства, способи судового захисту прав, свобод та інтересів в адміністративному судочинстві.

Статья посвящена исследованию содержания института украинской административной юстициии как разновидности правосудия, предметом которого в основном выступают публично-правовые споры, реализуемого в форме административного судопроизводства (административного проиесса) на основе судебной специализации. Раскрыты характерные черть административной юстиции, задачи административного судопроизводства, способы судебной защиты прав, свобод и интересов в административном судопроизводстве.
The article is devoted to the study of the content of the institute of Ukrainian administrative justice as a kind of justice, the subject of which is mostly the public-law disputes, which are implemented in the form of administrative legal proceedings (administrative process) on the basis of judicial specialization. The features of administrative justice, the task of administrative legal proceedings, methods of judicial protection of rights, freedoms and interests in administrative legal proceedings are revealed.

\section{Література}

1. Ківалов С.В., Картузова I.О., Осадчий А.Ю. Курс адміністративного процесуального права України. Загальна частина: підручник. Одеса: Фенікс, 2014. 342 с.

2. Загряциов М.Д. Административная юстииия и право жалобы в теории и законодательстве. Москва : Право и жизнь, 1925. 244 c.

3. Салищева Н.Г. О некоторых способах защиты и охраны прав, свобод и законных интересов граждан в сфере деятельности исполнительной власти в Российской Федерации. Конституциия Российской Федерации и совершенствование механизмов защиты прав человека. Москва, 1994. С. 77-85.

4. Бахрах Д.Н., Боннер А.Т. Административная юстииия: развитие и проблемы совершенствования. Советское государство и право. 1975. № 8. С. 13-21.

5. Чечот Д.М. Административная юстиция (Теоретические проблемы). Ленинград : Изд-во Ленинградского университета, 1973. 134 c.

6. Писаренко Н.Б. Засади адміністративного судочинства (сучасний український контекст) : монографія. Харків : Право, 2019. 248 с.

7. Курс цивільного процесу : підручник / В.В. Комаров, В.А. Бігун, В.В. Баранкова та ін. ; за ред. В.В. Комарова. Харків : Право, 2011. 1352 с.

8. Кодекс адміністративного судочинства України: науково-практичний коменmap / за заг. редакцією Р.О. Куйбіди. 2-е видання, доповнене. Київ : Юстініан, 2009. 976 c. 